\title{
Trade Creation and Trade Diversion Effects of the ASEAN-China FTA, ASEAN-Korea FTA, and ASEAN-India FTA Implementation on the export of Indonesia's Food and Beverages Industry Products
}

\author{
Wahyudi Setia Darma \\ Postgraduate Program in Economics, \\ Faculty of Economics and Business, University Indonesia \\ Depok, Indonesia \\ yudi7111@gmail.com
}

\author{
Fithra Faisal Hastiadi \\ Departement of Economics, \\ Faculty of Economics and Business, University Indonesia \\ Depok, Indonesia \\ fithra_faisal@yahoo.com
}

\begin{abstract}
This research is aimed to analyze the effects of trade creation and trade diversion which occured on the establishment of such cooperation for the export of Indonesian food \& beverage industry products with trading partners either with its members or non-members cooperation. This research was conducted by using a test from 12 countries in the period of 2005 - 2015, estimated using a modified gravity model by increasing the variable on dummy FTA as a proxy from the impacts on the implementation of ACFTA, AKFTA and AIFTA. The estimate results of this research indicate that the implementation of ACFTA, AKFTA and AIFTA gives positive and significant effect of trade creation and trade diversion on the export of Indonesian food and beverage products. This indicates that the implementation of ACFTA, AKFTA and AIFTA creates a trade creation effects by increasing intra-regional trade between ACFTA, AKFTA and AIFTA member countries and brings out trade diversion with non-member countries.
\end{abstract}

Keywords : ACFTA, AKFTA and AIFTA; Trade Creation; Trade Diversion; Gravity Model; Indonesian food \& beverage industry products.

JEL Classification : F13; L15.

\section{INTRODUCTION}

A Free Trade Agreement (FTA) is established between one country and another country. The Free Trade Agreement (FTA) experienced an increase during the last two decades and provided significant impacts to the development of international trade. Based on the report of the World Trade Organization (WTO) there are more than 270 schemes of regional Free Trade Agreements (FTA) that currently are actively applied in the world (WTO, 2015). This shows that the international trade development leads to a more free trade with various international cooperation patterns, either bilaterally or regionally.

The total free trades in the Asian region and its surroundings increased at the beginning of 2000. This is because Asia is considered as one of the emerging markets and made as the market target due to its above average economic growth. In addition, the expanding production networks, as the materialization and establishment of the Free
Trade Agreement (FTA), which is supported by productive manpower availability as well as abundant resources, makes Asia the target in the middle of the global economic crisis (ADB, 2011). The ASEAN free trade area (AFTA) is one of the FTA cooperation forms in the Asian region, which was established in 2002, and is the regional free trade agreement among the Southeast Asian countries. With regard to the implementation of AFTA, many circles value that this cooperation is not significantly increasing the trade among its members; and several studies mentioned that AFTA is not successful in increasing the trade volume of its members, one of those is according to the report of BKF. The Ministry of Finances indicated that the utilization rate of AFTA is only $30.43 \%$ (BKF, 2012).

Along with the global economic growth, the government of Indonesia ratified the establishment of FTA jointly with countries incorporated in ASEAN, in the frameworks of ASEAN-China FTA (ACFTA), ASEAN-Korea FTA (AKFTA), and ASEAN-India FTA (AIFTA), where such FTA had been fully implemented in 2010 (BKF, 2012). The joining of Indonesia, which is a country with the largest population and market in ASEAN, simultaneously provides consequences on two matters: the opportunities (a) to increase the market access of domestic products at the international market and (b) to challenge the domestic industrial competitiveness against foreign products.

One of the industries in the country that has the opportunity and is facing challenges due to this existing agreement implementation of ACFTA, AKFTA, and AIFTA is the food and beverage industry. The food and beverage industry products are commodities included in the ACFTA, AKFTA, and AIFTA agreements and this industry is one of the strategic industries that provides large contribution to the economy of Indonesia. During the period of 2011-2015, the food and beverage industry made $31 \%$ contribution to the GDP; it was the largest contribution from non-oil and gas processing industry. (Ministry of Industry, 2016). In addition, the food and beverage industry experienced a higher growth in 2015 . It made $8 \%$ growth, compared to the growth of the nonoil and gas industry of only $5 \%$. In view of the importance of the processed food and beverage industry toward the national economy, this industry is included in the group/cluster of 
priority industries, which is contained in the Regulation of the President of the Republic of Indonesia Number 28 of 2008 concerning National Industry Policy (Ministry of Industry, 2008).

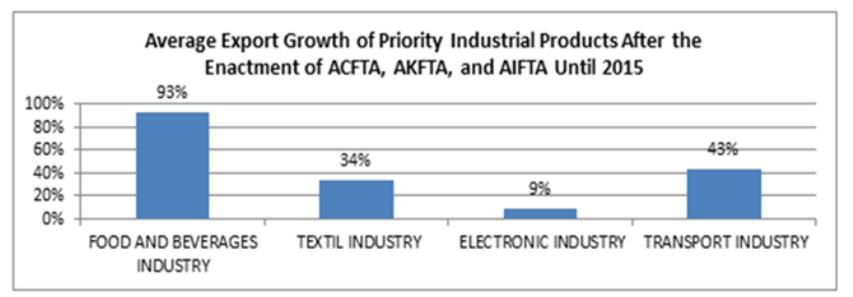

Figure 1.1 Average Export Growth of Indonesia's Food and Beverage Products by Country ACFTA, AKFTA, and AIFTA Until 2015

Source: World Integrated Trade Solution (WITS, 2017), has been reprocessed

Figure 1.1 shows that the food and beverage industry products experienced the highest growth of export to the member countries of ACFTA, AKFTA and AIFTA, reaching 93\%, compared to the other priority industries (textile industry, electronic industry and transportation equipment industry). The export trade value of the food and beverage industry products of Indonesia to the member countries of ACFTA, AKFTA, and AIFTA, increased after the FTA was fully implemented in 2010. The value of export to the member countries of ACFTA reached US\$ 3.99 billion in 2009, and increased to US\$ 6.99 billion in 2015. The value of export to the member countries of AKFTA was US\$ 2.06 billion in 2009 and increased to US\$ 3.84 billion in 2015. The value of export to the member countries of AIFTA was US\$ 5.50 billion in 2009 and increased to US\$ 6.95 billion in 2015.

The import trade value of food and beverage industry products of Indonesia from the member countries of ACFTA, AKFTA, and AIFTA, also increased after the FTA was fully implemented in 2010. The value of import from the member countries of ACFTA touched US\$ 1.14 billion in 2009 and increased to US\$2.23 billion in 2015. The value of import from the member countries of AKFTA reached US\$ 995 million in 2009 and increased to US\$ 1.92 billion in 2015. The value of import from the member countries of AIFTA was US\$ 1.09 billion in 2009 and increased to US\$ 1.96 billion in 2015. Picture 1.5 and Picture 1.6 show that the export values of the food and beverage industry products is higher compared to the import values.

Viner (1950) represented that the economic integration may cause the trade creation among member countries and/or cause the occurrence of trade diversion with non-member countries; so that the main question of this research is whether the increase of the export trade of Indonesian food and beverage industry products with the member countries of ACFTA, AKFTA, and AIFTA is the result of the trade creation effects due to the implementation of ACFTA, AKFTA, and AIFTA. Further on, whether such trade development causes the occurrence of the trade diversion on the Indonesian trade with the main trade partner countries of food and beverage industry products that are not members of ACFTA, AKFTA, and AIFTA. The main objective of this research is to analyze the effects of trade creation and trade diversion that occur due to the implementation of ACFTA, AKFTA, and AIFTA towards the export of the food and beverage industry products of Indonesia to the trade partners that are members of ACFTA, AKFTA, and AIFTA as well as to non-members of ACFTA, AKFTA, and AIFTA during the period of $2005-2015$.

\section{LITERATURE REVIEW}

The discriminative treatment occurs between the member countries in the economic integration and the nonmember countries outside the economic integration, so that it will affect the trade creation and trade diversion among the member countries (Salvatore, 2004). The basic objectives of the economic integration are to increase the goods and service trade volume, enhance the capital and manpower mobility, improve the productivity, improve the production efficiency, and increase the product competitiveness. Such condition will enhance the economic growth of member countries in an economically integrated region and thereby improving the community welfare.

Viner was the first person who explained about the differences of the trade creation and trade diversion effects that occur from the establishment of the custom union. This is a relevant international economic theory related to the economic policy on the economic integration. Viner uncovered that an FTA will be able to improve welfare based on the trade creation and trade diversion effects occurred. The economic integration will be very advantageous if the trade creation affects larger than the trade diversion (Viner, 1950). The trade creation basically occurs if the FTA is able to establish trade that never occurred before. Trade creation is the benefit obtained from the establishment of trade blocks, by assuming that all economic resources are fully used before and after the establishment of the custom union; so that the establishment of the custom union will improve the welfare of member countries that leads to the improvement of the production specialization based on the comparative superiority (Salvatore, 2004).

The trade diversion is a trade shift from non-member countries to member countries (Salvatore, 2004). The trade diversion occurs since the low-cost goods (lower-cost import) from non-member countries are replaced by high-cost goods (higher-cost import) from member countries. This happens due to the preferential treatment to fellow member countries, by reducing or eliminating tariff; so that the products from non-member countries, which are actually cheaper, become more expensive as they should bear the tariff (Salvatore, 2004).

An empirical research applying a gravity model was carried out by Jayasinghe \& Sarker, (2008), who investigated how the effects of trade creation and trade diversion occur from the RTA implementation on the export in the NAFTA member countries; the gravity model estimation was made by using two dummy variables, namely the trade creation and trade diversion. The empirical research was then developed in the RTA impacts analysis by using the gravity model that was 
modified by using three FTA dummy variables; those are trade creation, export trade diversion, and import trade diversion. The export trade diversion and import trade diversion showed the RTA impacts on the extra regional trade, where trade diversion was distinguished from the aspects of export and import in order to know the RTA impacts on the trade with non-member countries viewed from the aspects of export and import. Several researches applying this model were Endoh (1999), Carrere (2006), Zidi \& Dhifallah (2013) and Yang \& Martinez-zarzoso (2014). The research of Endoh (1999) was the first that used the term of export trade diversion that has a different definition from the trade diversion used by Viner (1950).

The impacts of the FTA implementation on trade may be distinguished based on its trade data analysis. Nearly most of the empirical studies aggregately used the trade data. The RTA implementation will also differently affect the commodity or product levels, in which generally the decline or reduction of tariff is distinguished based on each commodity or product. Several researches using the gravity model that was modified by using the trade data based on the sector or commodity trade are Yang \& Martinez-zarzoso (2014), Jayasinghe \& Sarker (2008), Urata \& Okabe (2010). Yang \& Martinez-zarzoso (2014) conducted an analysis concerning the trade creation and trade diversion impacts on the export in the ASEAN-China FTA region from 1995 to 2010 by using the aggregated and disaggregated export data for agriculture raw materials, manufacture goods and chemicals, as well as machine and transportation equipment. The result obtained from this analysis was that on the overall ACFTA provided trade creation impacts to its member countries. Meanwhile, Jayasinghe \& Sarker (2008) conducted the research in order to analyze the trade creation and trade diversion effects of the NAFTA member countries on the bilateral trade of agro-food products. Urata \& Okabe (2010) studied on 20 commodity groups based on SITC. The research found that the establishment of FTA will provide different results for each different commodity, where the establishment of the European Union (EU) was able to create the trade creation, particularly at the agricultural products, while for ASEAN the largest trade creation impacts occurred at the machine group, its derivative products and motor vehicles. This research referred to the studies done by Urata \& Okabe (2010) and Yang \& Martinez-zarzoso (2014), in order to analyze whether the establishment of ACFTA, AKFTA, and AIFTA makes trade creation or trade diversion impacts, particularly for the export of the Indonesian food and beverage industry products to both members and non-members of ACFTA, AKFTA, and AIFTA. No previous research used a product/commodity approach or focused on the trade creation and trade diversion effects on export of food and beverage industry products from the perspective of only one country, especially Indonesia. All studies done on FTAs discussed ACFTA, AKFTA and AIFTA. In addition, in order to answer the objective of the research, the dummy trade creation and trade diversion are used in the regression model by including the FTA implementation time element.

\section{METHODS}

\subsection{Model Specification}

This research used the gravity model in order to find out the trade creation and trade diversion effects on the establishment of an FTA adopted the research model conducted by Urata \& Okabe (2010) and Yang \& Martinezzarzoso (2014). The gravitation model in this research used the FTA dummy variable as proxy of the effects on the implementation of ACFTA, AKFTA, and AIFTA, which are the trade creation and trade diversion. The trade creation and trade diversion effects that occur are distinguished based on the membership status, namely the inter members (intraregional trade) and non-members (extra-regional trade); so that the model specification used in this research has the gravitation function and equation as follows:

$$
\begin{aligned}
\ln \left(X_{I, t}\right)=\alpha_{0}+ & \beta_{1} \ln \left(G D P_{t}\right)+\beta_{2} \ln \left(G D P_{I t}\right)+\beta_{3} \ln \left(D I S_{I}\right) \\
& +\beta_{4} \ln \left(\text { POP }_{I, t}\right)+\beta_{5}\left(F T A_{1_{I, t}}\right) \\
& +\beta_{6}\left(F T A_{2, t}\right)+\epsilon_{I, t}
\end{aligned}
$$

The explanation on the dependent variable and independent variable that are used in this research is as follows:

Export $\left(\boldsymbol{X}_{\boldsymbol{I}, \boldsymbol{t}}\right)$ as the dependent variable is the initial variable of the gravitation model (Tinbergen, 1962). The export that is used in this research showed the bilateral trade performance of the food and beverage industry products between Indonesia and the trade partners that are included in the member countries of ACFTA, AKFTA, and AIFTA and non-member countries (Yang \& Martinez-zarzoso, 2014).

The Gross Domestic Product $\left(\boldsymbol{G D P}, \boldsymbol{G D P}_{I, t}\right)$ is the total value of goods and service production in a country at a certain period. This research model used the real GDP, where the GDP variable that is used is the GDP of Indonesia $\left(\boldsymbol{G D} \boldsymbol{P}_{\boldsymbol{t}}\right)$ and the GDP of the trade partner countries $\left(\boldsymbol{G D} \boldsymbol{P}_{\boldsymbol{I}, \boldsymbol{t}}\right)$ (Urata \& Okabe, 2010).

The Distance $\left(\boldsymbol{D I} \boldsymbol{S}_{I}\right)$ is the geographical distance between the capital city (economy center) of Indonesia and the trade partner countries, either the member countries or nonmember countries of ACFTA, AKFTA, and AIFTA. This variable is used as proxy of the transportation costs (Urata \& Okabe, 2010).

Population $\left(\boldsymbol{P O P} \boldsymbol{P}_{I, t}\right)$ is the total population domiciled and settled in a country area. The population is measured with the inhabitant unit, which in this research is the population of the member countries ACFTA, AKFTA, and AIFTA as well as non-member countries (Urata \& Okabe, 2010).

The dummy variable FT $A_{1, t}$ has the value of 1 if the exporting country is Indonesia and the importers are the member countries of ACFTA, AKFTA, and AIFTA (country I) after 2009, and has the value of 0 if conversely. In case the coefficient of the $F T A_{1_{I, t}}$ variable has a positive value, then this variable shows the existence of the trade creation effect (Yang \& Martinez-zarzoso, 2014). 
The value of the dummy $\boldsymbol{F T} \boldsymbol{A}_{2}$ I,t variable is 1 if the exporting country is Indonesia and the importers are nonmember countries of ACFTA, AKFTA, and AIFTA (country I) after 2009, and has the value of 0 if conversely (Yang \& Martinez-zarzoso, 2014).

\section{RESULT AND DISCUSSION}

Two FTA dummy variables - the trade creation dummy (FTA1) and trade diversion dummy (FTA2) - were added to the main variable as proxy of the impacts on the implementation of ACFTA, AKFTA and AIFTA. The estimation result based on Table 4.1 showed the two main variable coefficients, namely the trade creation dummy (FTA1) and trade diversion dummy (FTA2) made positive and significant effects to the export trade of food and beverage industry products of Indonesia.

Table 4.1 Panel Data Estimation Results
\begin{tabular}{|l|c|c|c|c|}
\hline \multicolumn{1}{|c|}{ Variable } & KOEFISIEN & STD.ERROR & Z & P $>$ Z \\
\hline C & -8.291113 & 6.745116 & 1.97 & 0.219 \\
\hline LNGDPINDONESIA & $0.4335227^{* *}$ & 0.2198185 & 2.18 & 0.049 \\
\hline LNGDPOTHERCOUNTRIES & $0.4287036^{* *}$ & 0.1963213 & -2.11 & 0.029 \\
\hline LNDISTANCE & $-1.062397^{* *}$ & 0.5042299 & 1.17 & 0.035 \\
\hline LNPOPULATION & 0.3333781 & 0.3333781 & 4.54 & 0.244 \\
\hline VARIABLEDUMMYFTA1 & $0.6746171^{* * *}$ & 0.6746171 & 4.48 & 0.000 \\
\hline VARIABLEDUMMYFTA2 & $0.7089768^{* * *}$ & 0.7089768 & -1.23 & 0.000 \\
\hline$R^{2}$ & 0.5256 & & \\
\cline { 1 - 2 } WALDCHI 2 & 493.84 & & \\
\cline { 1 - 1 } PROB $>$ CHI 2 & 0.0000 \\
\hline
\end{tabular}

The trade creation dummy (FTA1) variable showed a positive coefficient value of 0.6746171 and significant probability at $\alpha=1 \%$, and this shows that the trade creation effect of the ACFTA, AKFTA and AIFTA implementation gave significantly positive effect on the bilateral export trade of food and beverage industry products of Indonesia to the member countries of ACFTA, AKFTA and AIFTA.

The export of food and beverage industry products of Indonesia to member countries of ACFTA, AKFTA and AIFTA experienced a quite significant increase after the enforcement of those three FTAs. The export value of Indonesia to the member countries of ACFTA reached US\$ 3.99 in 2009 and increased to US\$ 6.99 billion in 2015. The export value of Indonesia to the member countries of AKFTA was US\$ 2.06 billion in 2009 and climbed to US\$ 3.84 billion. The export value of Indonesia to the member countries of AIFTA made US\$ 5.50 billion in 2009 and went up to US\$ 6.95 billion.

The average export growth of food and beverage industry products of Indonesia to member countries of ACFTA, AKFTA, and AIFTA increased after the full implementation of the FTAs in 2010. The average growth of export prior to the enforcement of ACFTA, AKFTA and AIFTA was $12 \%$ and significantly increased to an average of $38 \%$ after the enforcement of those three FTAs. The export of food and beverage industry products in 2015 was dominated by exporting to China which valued US\$ 3.87 billion.

The trade diversion dummy (FTA2) variable made a positive coefficient value of 0.7089768 and significant probability at $\alpha$
$=1 \%$, which shows that trade diversion effect from the implementation of ACFTA, AKFTA and AIFTA has a positive and significant effect on the bilateral export trade of food and beverage industry products of Indonesia to the main trade partners that are non-member countries of ACFTA, AKFTA and AIFTA. The positive and significant value at the trade diversion variable indicates that the implementation of ACFTA, AKFTA and AIFTA did not cause the trade diversion; and the increase of the extra-regional trade of food and beverage industry products of Indonesia occurred with the main trade partners that are non-member countries of ACFTA, AKFTA and AIFTA.

The non-member countries of ACFTA, AKFTA, and AIFTA that are included in the main trade partners of food and beverage industry products of Indonesia are Argentina, Australia, Brazil, Netherland and United States of America. The export of Indonesian food and beverage industry products to those countries increased after the full implementation of ACFTA, AKFTA, and AIFTA in 2010. The export value of Indonesia to Argentina was US\$ 50.1 million in 2009 and increased to US\$ 150.4 million in 2015. The export value of Indonesia to Australia was US\$ 110.4 million in 2009 and climbed to US\$ 168.8 million in 2015. The export value of Indonesia to Brazil reached US\$ 125.9 million in 2009 and went up to US\$289.2 million in 2015 . The export value of Indonesia to the Netherlands touched US\$ 131.6 million in 2009 and increased to US\$ 171.3 million in 2015. The export value of Indonesia to the United States of America was US\$ 570.3 million in 2009 and increased to US\$ 1.95 billion in 2015

The average growth of export of the Indonesian food and beverage industry products to the non-member countries prior to the implementation of ACFTA, AKFTA and AIFTA was $7 \%$ and increased to an average of $18 \%$ after the enforcement of those three FTAs.

The GDP variable of Indonesia $(\boldsymbol{G D P})$ has a positive coefficient value of 0.4335227 and significant probability at $\alpha=5 \%$. This shows that the GDP of Indonesia has a positive and significant effect on the export of food and beverage industry products of Indonesia. This research used the GDP as proxy of the production of food and beverage products of Indonesia.

The GDP variable of the trade partner country $\left(\boldsymbol{G D} \boldsymbol{P}_{\boldsymbol{I}, \boldsymbol{t}}\right)$ has a positive coefficient value of 0.4287036 and significant probability at $\alpha=5 \%$. This shows that the GDP of the trade partner countries has a positive and significant effect on the export of food and beverage products of Indonesia. The GDP of trade partner countries shows the consumers purchasing power of the trade partner countries.

The Distance $\left(\boldsymbol{D I} \boldsymbol{S}_{I}\right)$ variable, as proxy of the distance in the gravity model has a negative coefficient value of -1.062397 and significant probability at $\alpha=5 \%$. This shows that the distance has a negative and significant effect on the export of food and beverage products of Indonesia. This estimation result is in accordance with the research hypothesis or theory, which explains that the larger the inter-country distance, then more the implemented trade is declining. 
The population variable $\left(\boldsymbol{P O P} \boldsymbol{P}_{I, t}\right)$, as proxy of the total population of the trade partner country has a positive coefficient value with non-significant probability of 0.244 , which is larger than the significance level of $10 \%$. This shows that the population of the trade partner country $\left(P O P_{I, t}\right)$ has statistically no significant effect on the export of food and beverage products of Indonesia.

\section{CONCLUSIONS}

The positive and significant value of the trade creation variable indicates that the implementation of ACFTA, AKFTA and AIFTA was able to create the trade creation by increasing the intra-regional trade of the food and beverage industry products of Indonesia with the member countries of ACFTA, AKFTA and AIFTA.

The significant increase of the intra-regional trade with ACFTA, AKFTA and AIFTA was due to the implication of the existing preferential tariff applied among the member countries of ACFTA, AKFTA and AIFTA. In addition, the estimation result of this research indicates that the trade creation from the implementation of ACFTA, AKFTA and AIFTA might provide large opportunity for the market access of the food and beverage industry products to China, Korea, India and ASEAN, where the market opportunity of 3.3 billion people is created.

This research also shows that the trade diversion significantly made positive effect from the implementation of ACFTA, AKFTA and AIFTA on the export of food and beverage industry products of Indonesia to the main trade partner countries that are the non-member countries of ACFTA, AKFTA and AIFTA. The positive and significant value of the trade diversion variable indicates that the implementation of ACFTA, AKFTA and AIFTA did not cause the trade diversion; and the extra-regional trade on export of the food and beverage industry products of Indonesia increased with non-member countries of ACFTA, AKFTA and AIFTA.

The estimation result of this research also shows that the implementation of ACFTA, AKFTA and AIFTA was not only increasing the intra-regional trade among the member countries of ACFTA, AKFTA and AIFTA but is also increasing the extra-regional trade with non-member countries of ACFTA, AKFTA and AIFTA, without causing the occurrence of trade diversion.

\section{References}

[1] ADB. (2011). EE Asia's Free Trade Agreements How is Business Responding ? Asian Development Bank.

[2] BKF, P. K. R. dan B. (2012). Free Trade Agreement (FTA) dan Economic Partnership Agreement (EPA), dan Pengaruhnya terhadap Arus Perdagangan dan Investasi dengan Negara Mitra. Laporan Hasil Kajian.

[3] Carrère, C. (2006). Revisiting the effects of regional trade agreements on trade flows with proper specification of the gravity model. European Economic Review, 50(2), 223-247.

[4] Endoh, M. (1999). Trade Creation and Trade Diversion in the EEC, the LAFTA, and the CMEA. Applied Economics, 31, 207-216.
[5] Jayasinghe. S, \& Sarker. (2008). Effects of Regional Trade Agreements on Trade in Agrifood Products: Evidence from Gravity Modelling Using Disaggregated Data. Oxford Journal. Agricultural \&Applied Economics Associations, 30(1), 61-81.

[6] Salvatore. D. (2004). International Economics (8th ed.). USA: John Wiley and Sons, in.

[7] Tinbergen. J. (1962). An Analysis of World Trade Flows. (J. Tinbergen (ed.): in Shaping the World Economy, Ed.). New York: The Twentieth Century Fund.

[8] Urata, S., \& Okabe. (2010). Trade Creation and Diversion Effects of Regional Trade Agreements on Commodity Trade. RIETI Series 10-E007.

[9] Viner, J. (1950). Customs Union Theory. Carnegie Endowment for International Peace. New York.

[10] WTO. (2015). Regional trade agreements by WTO member, diakses April 2017. Retrieved from http://www.wto.org.

[11] Yang, S., \& Martinez-zarzoso, I. (2014). China Economic Review A panel data analysis of trade creation and trade diversion effects: The case of ASEAN - China Free Trade Area. China Economic Review, 29, 138-151. http://doi.org/10.1016/j.chieco.2014.04.002.

[12]Zidi, A., \& Dhifallah, S. M. (2013). Trade Creation and Trade Diversion between Tunisia and EU: Analysis by Gravity Model, 5(5), 131-147. http://doi.org/10.5539/ijef.v5n5p131. 